\title{
A Conversation with Sandra Abell: Science Teacher Learning
}

\author{
Patricia J. Friedrichsen \\ University of Missouri-Columbia, Columbia, MO, USA
}

Received 9 January 2008; accepted 22 January 2008

The conversation between Sandra Abell and Patricia Friedrichsen took place at the University of Missouri, U.S., on December 19, 2007. The purpose of this dialogue was to reflect on Dr. Abell's career in science education and her research on science teacher learning. During the conversation, Sandra Abell discussed changes in research in this field, the usefulness of the pedagogical content knowledge construct, as well as directions for future research. The text includes a brief summary of Sandra Abell's career achievements, a list of our conversation topics, the transcript of the audio-taped conversation, as well as a list of Dr. Abell's selected publications.

Keywords: Science Teaching Learning, Pedagogical Content Knowledge

\section{FOREWORD}

Sandra K. Abell is the Director of the Science Education Center at the University of Missouri, U.S. Dr. Abell is a Curators' Professor of Science Education and is jointly appointed in the Department of Teaching, Learning \& Curriculum and the Division of Biological Sciences. Dr. Abell received her Ph.D. in Science Education from the University of Iowa (1988); a M.A. in Talented and Gifted Education from the University of Northern Colorado-Greeley (1981); and a B.A. in Elementary Education from the University of Iowa (1977).

Dr. Abell began her career as an elementary teacher, teaching in Iowa and New Mexico (U.S.), and Iceland. Dr. Abell's elementary teaching career focused on both science teaching and multicultural, gifted and talented education. Dr. Abell's first appointment in higher education was at Purdue University, where she moved through the ranks of assistant to associate to full professor of science education (1988-2000). Dr. Abell has taught a variety of university courses, including science teaching methods courses for pre-service elementary teachers, secondary teachers, and university science teachers, as well as graduate research courses in

Correspondence to: Patricia Friedrichsen, PhD

Science Education, MU Science Education Center, 321E

Townsend Hall, University of Missouri, Columbia, MO

65211, USA

E-mail: FriedrichsenP@missouri.edu

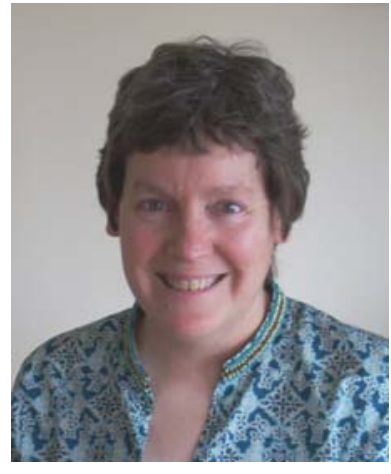

Figure 1. Professor Sandra K. Abell

science education. Dr. Abell has received numerous teaching awards throughout her career, including the Association for the Education of Science Teachers' (AETS, now ASTE) Award for Outstanding Science Teacher Educator (1996), the AETS Award for Innovation in Teaching Science Teachers (1997), and the AETS Outstanding Mentor Award (2005).

Dr. Abell is internationally known for her research on science teacher learning. She has presented 117 papers at international and national conferences, and published 58 refereed journal articles. Dr. Abell has authored 14 book chapters and edited 3 books, including the Handbook of Research on Science Education (2007), which she co-edited with Norman Lederman. In recognition of her efforts to advance science education, Dr. Abell was elected as a Fellow in the American Association for the Advancement of Science (AAAS) in 2004 . 
Throughout her career, Dr. Abell has been active in professional organizations, including ASTE, the National Association for Research in Science Teaching (NARST) and the National Science Teacher Association (NSTA). She has served on a variety of committees within these organizations, as well as serving on the NARST Executive Board (1995-1998) and the AETS Executive Board (1997-2000). From 1993 to1998, she served as the Associate Editor for the Journal of Research in Science Teaching. Most notably, Dr. Abell served as NARST President in 2000-2001.

\section{INTRODUCTION}

Sandra Abell and I attended the 2007 European Science Education Research Association Conference (ESERA) in Malmö, Sweden. The ESERA presentations were thought-provoking, helping me generate new research connections and ideas. More important to me, though, were the informal conversations that took place in the conference hallways, hotel lobbies and while enjoying smorgasbords in charming Swedish restaurants. During the conference, Fatih Taşar, the associate editor of the Eurasian Journal of Mathematics, Science and Technology Education, asked me to interview Sandra Abell for a new series in the journal. I was intrigued with Fatih's proposal and agreed to conduct the interview. I view this new interview series as a way to provide graduate students and novice researchers access to the types of beneficial, informal conversations that took place at ESERA. As a faculty member of the MU Science Education Center, I have worked closely with Sandra for the past five years. During this time, my conversations with Sandra have helped shape my research. Surprisingly, though, I learned some new things about my colleague during this interview, as I hope you will, too.

\section{CONVERSATION TOPICS}

To guide the listener/reader in this conversation with Sandra Abell, I have provided a list of our general conversation topics:

- Sandra Abell's career pathway that led to researching science teacher learning;

- Changes in research perspectives on teacher learning, including the current U.S. policy favoring "scientifically-based" research;

- Research informing the design of science teaching methods courses, including courses for pre-service elementary teachers, secondary teachers, and university-level science teachers;

- The usefulness of the construct of pedagogical content knowledge (PCK), including advice for novice PCK researchers;
- Achieving balance between research and teaching in one's academic career, including writing tips.

In this section, I provide a verbatim transcript of the audio-taped conversation which is available on the journal's webpage.

PF: I am Pat Friedichsen at the University of Missouri-Columbia and today I am having a conversation with Sandra Abell, my colleague, about science teacher learning research. So, Sandi, tell me what experiences led you to do research in science teacher learning?

SA: Well, I started my career as an elementary school teacher and I think I received really good preparation to be an elementary school teacher at the University of Iowa. While I was an elementary school teacher I started to do professional development for other teachers and got very interested in how I could have an effect beyond my classroom. That's when I went back to school, went back to the University of Iowa for a Ph.D. I think it was just a natural for me to fall into research about science teacher learning because I had always been a teacher, always wanted to be a teacher or was a teacher, and I was very interested in what made some teachers excellent, what helped teachers become better teachers, those kinds of questions. So I think it was just a natural fit between my interest in being a teacher and my own professional development, and then wanting to study that with other teachers.

PF: I think it was a very similar reason for me as well, how I went down that path. Tell us more about your research career. Did you start out focusing on elementary science teacher learning? Kind of talk us through the path that you took.

SA: I was certainly very interested in elementary teacher learning and elementary teacher education for a big part of my career. I felt like that was where I could make sense of the world, of elementary schools and that is what I really cared about, what was going on in elementary schools. I was engaged in teaching methods courses for elementary teachers. So it seemed sort of a natural connection to have my job as a science teacher educator overlap with my interest in doing research on teacher learning. My dissertation was focused on professional development of middle school teachers. Pretty much for the first ten, twelve years of my career I focused on looking at pre-service elementary teachers and their experiences learning in methods courses and beyond method courses, their experiences learning in student teaching, and then how they developed as teachers beyond the pre-service program. Professional development types of things.

PF: Since I have known you here at the University of Missouri your research interest has been broader than that. So what caused that broadening of interest? 
SA: I think the shift occurred when I moved to Missouri because my position here was different. Instead of coming here to teach elementary methods I came here to run the Science Education Center. As we looked around to see what were the biggest problems that needed our attention at that time, the shortage of qualified science teachers became a really driving force. We ended up, we being a team of people at Missouri, ended up developing some new programs for recruiting and preparing middle and secondary teachers in a kind of alternative certification setting. Then it made sense to start studying how those people learn. The other new thing that happened at that time was that I was jointly appointed in the Biology Department and the goal of the folks who hired me to do this joint appointment was that I would think about preparing graduate students in the sciences and faculty members in the sciences for being teachers. We developed new courses and we started to study teacher learning at the college level. So, I would say, yes, my research interests have broadened in terms of the scope of teacher learning and that really I am interested in science teacher learning elementary through college. But, the focus is still how people figure this really complicated thing out, the complicated thing being science teaching. How do people come to do a better job at science teaching? I think that has been the driving force for me all along.

PF: Let's take that last question and think about that from a researcher's perspective. How have perspectives changed in the field on researching teacher learning over the years? From when you started researching to today? Was your dissertation similar to the work you do now?

SA: Oh, absolutely not. Now you are making me feel old. Way back then, in the 80 s when I was a student at the University of Iowa, there was still quite a bit of process-product research being done looking at teacher effectiveness in terms of teacher as a technician. If we ask teachers to do a particular strategy, will they be able to do that strategy or not? We were sort of at the end of that era, at the same time we were beginning a new era which was looking at teachers as not just the subjects of our studies, but teachers as experts. Teachers as, what Gary Fenstermacher calls the "known versus the knower"(Fenstermacher, 1994). So we used to look at teachers as something to know and we started looking at teachers as knowers. People who had something to offer to our research and that started to change the way we went about doing research from doing research on teachers to doing research with teachers. So back to my dissertation, it was a very much process-product dissertation where we had done professional development with a group of teachers and we went out to study the effect of the professional development on their teaching behaviors. We looked at: Did teachers ask more open-ended questions? Did teachers use particular kinds of assessments? It was very much we had given them this knowledge, now were they using it?

PF: Did you interview them at all or did you only observe? Was it your perspective?

SA: It was observation only. We took videotapes of them; we coded videotapes for teacher behaviors. It was very reductionist and very much "the teacher is the subject of the study." I published my dissertation, but, curious enough, I never got my dissertation bound, because somehow I knew that that was not the kind of research I wanted to do.

PF: Interesting.

SA: There was nobody at that point of time on my committee who was looking at the kind of new wave of educational research which was going on at the time which was the whole move toward qualitative research. So I sort of had to learn some things on my own about that. When I went to Purdue where I had my first job as a professor, I started attending classes on qualitative research, both in the College of Education and in the Anthropology Department, so that I could learn more about these methods that I thought would be a better fit for the kinds of studies that I wanted to do. I wanted to look at teacher learning in some other way that was not this reductionist way.

PF: So let me ask you to reflect on the role you think you have played in science education in shifting that focus to qualitative research.

SA: I can tell you that I was on the Editorial Board of The Journal of Research in Science Teaching in the late 80s and early 90s. The movement toward qualitative research had sort of happened in other fields, English education for example. It was a little slower in science education and I think one of the reasons is because we were holding more to that "Scientific Ideal" (that would be a little different discussion about what is the nature of science). I think it was harder for science educators to move toward the qualitative perspective. I do remember being on the Editorial Board of JRST with Nancy Brickhouse, and Ron Good was the editor. At one point we were having a discussion about the criteria that we were using to review manuscripts. Nancy and I were basically making the argument that the review criteria were biased and not inclusive of new methodologies that were becoming available. So, Ron invited us to redo the criteria for review of those manuscripts, which Nancy and I did, and that led to a publication (does not have our names on it), but it was a publication in the journal about how the reviews would be done in the future (Good, 1993). I think it was a very important piece of work because we were influencing the way that manuscripts would be reviewed and be accepted or not accepted into the journal. I feel very proud of that work that Nancy and I did.

PF: I think that is work that younger researchers had no idea of the "behind the scene" piece that occurred. 
SA: At the same time it was interesting at NARST [the National Association for Research in Science Teaching], there were groups popping up that were debating the pros and cons of this new methodology, and also groups that were trying to defend qualitative research. Certainly Ken Tobin was a leader in some of those discussions. I remember faithfully going to those discussions and trying to move the agenda forward and then I had the opportunity to become the Associate Editor of the Journal of Research in Science Teaching while I was at Purdue. We talked a lot about the kinds of methodologies that we would like to promote as editors and I think we even put together an editorial that talked about moving toward a mature discipline of science education research that could help young researchers feel like they did have a place in the science education community with the kinds of research that they were doing.

PF: So Sandi, now I want to ask you about this relatively new shift in policy in the United States as a call back to quantitative research as being more scientifically-based(e.g., Shavelson \& Towne, 2002). What is your reaction to the current U.S. policy?

SA: A couple of years ago we put together a special session at NARST about that topic. I think that the bottom line was that that was a very limited view of educational research. I would say I am not antiquantitative. I think that those wars are long gone. What we should be thinking about are what are the important questions that need to be asked and what are the best ways to go about answering those questions, be they qualitative, quantitative, mixed methods, what have you. I think that this view of "scientifically-based literature" is flawed on many levels. I think that it is interesting that we hold up scientific research and some time we include medical research in that, as sort of the model for our work. Yet medical research has been held up as really not having made much progress since the days of putting leeches on people's backs to solve the problem, whatever problem of the day was. So I think that we need to have a more broad view of how we can go about answering questions, in ways that will move our agendas forward-whether they are medical agendas, scientific agendas or science education agendas. It is just the problems are too big to be solved by any one methodology.

PF: I completely agree with you. We have been talking about shifts in methodologies and changes. I want to go back to science teacher learning as a construct. So, what have we learned about how teachers learn? What progress have we made in this field about what we know-how to support teacher learning?

SA: I think it is a great question and we could probably write a book about that. I think we do know quite a bit. We know a lot about, for example, science teacher subject matter knowledge. But rather than, I guess I want to evade your question for just a minute, and think instead about how our views of teacher learning have shifted to help us think about different questions to ask and the answers to those questions are moving us forward in science teacher education practice. Maybe that is the most important thing. Science teacher education research is very practical. It is not basic research; it is research that needs to be done if we are going to improve how we prepare teachers. So, I think the biggest shift in thinking from this thing I was talking about, teacher as technician, teaching people a set of skills or strategies, to thinking about teachers as knowing individuals and thinking about how, say a conceptual change approach could really affect the way we look at our research. So what happened in the 90s, is that a lot of people started to think about teacher learning in science from this conceptual change approach. We started to study what do students know when they come into programs. So instead of thinking of people as blank slates that we needed to teach particular strategies to, we started to say we know that they have been in the apprenticeship of observation of science teaching for 18-20 years, probably 15 years (Lortie, 1975). We know they have views coming in about what science teaching and learning ought to be. Now we actually have some research, some empirical data, that tell us, yes they do have these views, these preservice teachers have these views about science teaching and learning when they come into teacher preparation programs. More importantly, those views do not match the views that are being promoted by the science teacher educators in the teacher education programs. So we have a mismatch between what we are trying to accomplish in teaching teachers and what they come to us already knowing and believing. That finding is critical for thinking about how to do teacher education. If we know they have these views, then it is going to be our job, as teacher educators, to bring those views to light, to challenge those views and then to help them to see intelligible, plausible, alternative views of science teaching and learning. I think that has led to, for example, greater use of case-based instruction in teacher education. So that students can actually see video examples or read text examples of science teachers in action, and see how those views might differ from the views they have always seen of "teachers as tellers" and "learners as listeners."

PF: I very much had this "ah ha" moment a few years ago when I went out and watched my student teachers teach a 5E [lesson] and they thought they were doing what I, we thought we were talking about the same thing (Bybee, 2002). I saw very clearly that we were not talking about the same thing.

I wanted to ask you about, you teach a rather unique course, a methods course, but, it is a college science teaching course. Now these are Ph.D. students in 
sciences who are interested in teaching. So their apprenticeship of observing science teachers is even longer. How has your research in science teacher learning influenced what you do in that one semester course that you have with these people, who will probably never take another methods course or another education course?

SA: I think that is an interesting question. Now I have taught methods courses for elementary, future elementary teachers, future secondary, middle and secondary teachers and these future college science teachers. I have to say that overall the same research findings are helpful in thinking about structuring those courses. In every case, we know that these people have a very limited view of what science teaching could look like and need to have some new views, some new pictures of science teaching. In the college science teaching course, we try to show them the best scientists who teach undergraduate courses on campus. We try to show them examples of folks on campus who are doing different kinds of things in order to let them see the alternative views. I would have to say, though, I think the biggest difference in teaching college science teaching folks is that we have to be aware of the constraints that they are going to face. Those constraints that they are going to face, as teachers, are very different from what a future elementary school teacher might face. They may have 300 people in a large lecture class so we have to think about what does best practice looks like in a lecture setting. We have to be realistic of what we expect these people to be able to do. For example, I think in the past science educators may have gotten a bad name for saying lecture is bad, but not giving any alternatives. The fact of the matter is that lectures could be good. So one of the things we do in the course is we try to think about what makes a good lecture. How does all of that come back to research? Since I have been here at Missouri we have been working with some college science faculty, watching them teach and watching them think about their teaching, and trying to figure out where these points of constraint are and where we can make progress. A recent study we looked at, what do college teachers think about inquiry? I think one of the findings was really very important. They have this view of inquiry like many people in science education I would say, that says what the best instruction is, is open and full inquiry where students come up with research questions and follow through on investigations. That is their view of what they should be doing.

PF: But, it is unobtainable.

SA: It is unobtainable. It is absolutely unobtainable and they have no alternative views. That finding has helped us think about what do we need to do to help these folks move toward inquiry in what we are calling achievable inquiry, in ways that work for the constraints that they face in their classroom teaching.

PF: This led to a current professional development workshop that you are doing with college faculty and we have a joint doctoral student who is studying this.

SA: That is right.

PF: Do you want to talk briefly about how that led to the next stage?

SA: I worked with several science faculty on campus who has been doing very innovative things in their instruction. One of the things they have been doing is thinking about laboratory instruction differently and trying to move away from cookbook laboratories into laboratories that emulate the work of scientists in very structured ways, not in this full and open inquiry way. My colleagues in the sciences have gotten grant funding from our National Science Foundation to take their ideas and to do professional development with other college science faculty to help them think about how they can restructure their laboratory instruction. One of the things, last year we had a summer institute for these college science faculty, as well as their graduate students. One of the ideas we introduced was the finding from our study about college science teachers' views of inquiry. We showed them the common view and we showed them our view and we called it achievable inquiry. And there was a sigh of relief through the whole audience when we talked about that idea. They realized that they, too held that unobtainable view, but the folks that were facilitating the workshop did not. Then they started to say, maybe I can change things in my instruction that will help students take more responsibility for their learning. Get them more engaged with thinking about science, but, not to the extent that it will totally disrupt the structure of the laboratory and what I am capable of doing.

PF: I think you have given some really nice examples of how research and teaching are just two sides of the same coin. I think we both feel this way of how our research informs what we do in our teaching and that they are not separate ventures that we are engaged in and that it is a package for us.

SA: I think maybe we are lucky as science teacher education researchers, because we have figured out a way to get more mileage out of the work we do. We are not always sure of when we are teaching and when we are researching, because they are happening simultaneously. Then our research is fitting back into our practice quite naturally. I think we are the lucky ones.

PF: I agree. I think it just makes a more coherent whole for me when that does work.

SA: Yes

PF: Recently you completed a major project with Norm Lederman as the co-editors of the new handbook. You authored one of the chapters in the 
handbook on science teacher learning and you choose to organize your chapter around the construct of pedagogical content knowledge (PCK). You spent quite a bit of time on this project so I want you to talk about PCK. So PCK is a very attractive construct to me, I will be real honest about that. So we have seen lots of people play with it and we have seen people pull away from it and now, it is coming back into popularity. From your work on that chapter, I would like you to talk to me about the advantages and the limitations of this construct. What does this construct buy us? What do we gain from this? Are there limitations with this construct?

SA: These questions are near and dear to my heart, because I just finished writing a closing piece for a special issue of the International Journal of Science Education that is just about PCK. I asked myself those kinds of questions. I have to admit that PCK is very attractive concept for me and it has been since I first learned about it. It helps me think about this work that I do with teacher learning and teacher education. It gives me an organizer for thinking about the goals I have for science teachers. What do I need to know about them as science teachers? How I can help them progress as science teachers? The idea that Shulman (1986) talked about, that there is special knowledge for teachingPCK-that only teachers have. Then Magnusson and some other folks (1999) in science education took that to the next step and helped us think about what are the components of PCK? It is those components, I think, that really help us think about teaching practice and help us think about doing research. It also helped me organize that chapter in the handbook.

PF: Huge chapter.

SA: I used those components to look at the various threads of research. I think the problem with the construct right now is not the construct itself, but how it has been used or misused or only partly used in the research. I tried to talk about that in the handbook chapter, that it seems to me often in science education research, we like to invent new constructs rather than using the good constructs that we already have.

PF: Or new terms for well established terms.

SA: That is right. I think that we have not gotten to use the PCK construct to its fullest extent. I think there is a lot that we do not know about science teacher knowledge and the development of that knowledge that the PCK construct could help us with. If we are more interested in developing new terms, (you can look at the chapter to see what some of the terms might be), then we are not really making good use of the construct, the PCK construct, that exists. I think that there are some challenges in that, but, mostly, I think there are opportunities. There is lots of research that needs to be done about what science teachers or future science teachers know about learners, about curriculum, about instruction, and about assessment. When do they know those things? Is there a developmental trajectory for those kinds of knowledge? How do we, as science teacher educators, help them build those kinds of knowledge? I think the construct is very useful, but there is a lot of work that still needs to be done. Besides developing some models of teacher knowledge and teacher development of knowledge, I think we have to move beyond some of the descriptive research that we are doing. Descriptive research is really good, it is really important and I have done quite a bit of it. We do need good cases that show us examples of teacher learning. We need to move beyond, to think also about the why question. How do we explain teacher learning and how do those explanations then help us build these models for teacher learning? I think that is going to be the harder thing to get at. That is because every researcher's life is short and because, often times, we have a desire to produce studies that could lead to more quick results and some of these questions are questions that really take a long time to investigate.

PF: I agree. For me our questions need to be focused on the longitudinal. Our system in the United States of promotion and tenure does not support these long-term studies that are really going to help us answer what, I think, our questions are at this point.

SA: I think that is true. I think that is true in the United States of our doctoral programs.

PF: Yes.

SA: I have seen some European models that I think are much better models of getting doctoral students engaged in research early on, that's going to be a research program for them over five years in their doctoral programs. I think at Missouri we engage students in a lot of research early on, but, we do not necessarily help them construct a thread of research throughout their programs.

PF: I think that is partially the way we are set up for intensive course work early in the program, that there is not time.

SA: Yes, I think so.

PF: I am going to ask you about advice on two different levels. The first one is, if someone came to you and wanted to get involved and focus on PCK research, I know you give some advice in the chapter, would you like to repeat some of that? So people who are new to the field and would like to get involved in it. What are some cautions or recommendations that you would make? You talked about building on what we already know.

SA: I think that is really critical. I have been in too many presentations at too many conferences where people have not done their homework. Going back into the literature to look at the history of the ideas and how they have developed. I think in the PCK literature and science education, we have a strong foundation and we 
should build on that. I think I would advise a new researcher to think about moving from quantifying PCK (I do not mean that in terms of quantitative or qualitative research, but in terms of defining what PCK people have) to also thinking about the quality issue. What is the quality of teacher knowledge that people have and how do they, not only possess this knowledge, but use it to solve classroom problems? I think teacher knowledge is a very active kind of thing. We cannot look at it as a static, kind of write down what knowledge do you have at this point and time. We have to look at it in terms of how you are using that knowledge to solve practical problems of teaching and learning. I think that advice would be really important. Build on the past; make sure you understand the nature of the construct, and some of the controversies. There are some different camps if you will, about what PCK is and is not. It is probably helpful to understand those camps and then align yourself with one of those or more than one of those. Then to get beyond what we already know. Do not do yet one more study of teacher beliefs coming into a program.

PF: We know a lot about that.

SA: We know a lot about that. Now we need to move on and think about these kind of knowledge in use questions and quality questions. Eventually we need to answer the most important question of all. Does teacher knowledge making any difference in their practice and does that make it any difference in student learning? We have these hypothesized connections on those three pieces, but, we do not have a lot of empirical evidence about those connections. So I would also encourage young researchers, but, also practicing, veteran researchers, to think about moving us forward to make those links, help us know more about those links.

PF: On a practical level there are all sorts of issues and harder to get at. I think that link is critical because we are making assumptions there about the connection to student learning.

SA: To be fair to those people who are scientificallybased research policy makers, I think in the end their heart is in the right place because they are interested in having research findings that tell us something about the connection between teacher learning and student learning. I think that part of the policy is right-minded. I just do not think that the conclusion-therefore, we need more experimental studies-is necessarily correct.

PF: Now I am going to ask you to give a broader recommendation. You have been a very successful researcher and teacher. You have balanced the different components that are required of people in higher education. So what recommendations would you give for new faculty just starting out in academic positions on balancing teaching and research and some tips for research in general, beyond PCK?
SA: The balance question is interesting. I think I kind of answered it earlier when we were talking about how lucky we are to be teacher education researchers. One of the ways I have achieved balance is to make sure my research plays into my teaching and back and forth so that I am not doing two totally unrelated activities. On the other hand (probably I do not know how many people I have advised on this very basic part of balance) you have to put it into your schedule if you are going to do it. I schedule writing time; I schedule preparation time for preparing for class. I schedule exercise time. And if it gets on my schedule it will get done. If it is not on my schedule, it will not get done. I think it is very important because the teaching can be overwhelming. We could all spend our entire career improving our teaching. Yet we know we have these other parts of what it means to be a science educator, that we need to take care of, and what it means to be a person, a parent, a friend, a child, whatever it might be. We have to make sure we are addressing those things and that is only going to happen, I think it is only going to happen, if we put it into our schedules and make sure it happens.

PF: You recently talked about a writer's block that occurred in writing a chapter. This is a conversation that we had awhile back. I remember some things that you said about what you discovered helped you get through that. It was advice that I sort of held on to.

SA: I think I have given this advice to other people and maybe had not taken it myself. So it was good for me to take it myself. When students come to me and say I am in this analysis quandary and I do not know what to do next, I often send them back to the library to do more reading. I think when I got that writer's block I went back and re-read some things I thought I was pretty familiar with, as well as read some new things. I think that reading is absolutely critical. We have to always be playing our ideas off of what is out there in the literature. My reading pile is pretty big, but that is important. I think the other thing that is really critical and writing teachers will tell you this for sure. If you have a writer's block, you have to write. Even if all of you write is "I am having writer's block." When I was having that writer's block, the worst thing that I think I could have done was to stop writing and to put the writing off. Instead, I just kept going back to the piece. Even if I wrote a paragraph in the morning I was still writing. So to me reading, writing and the third piece that is absolutely critical is talking to other people. If we really do believe all of that stuff about social learning, then we have to apply it to ourselves and think about, if I go out to lunch with you, Pat, and start talking about this it is going to help me think through some of the issues I am having. I might start constructing new knowledge by talking through it. I think that collaborating with others is absolutely a critical part of my career. It is the most fun part of my career and it is 
the most rewarding part of my career. You learn so much by working with other people and I would not be here today having this conversation, if it had not been for the classroom teachers I have collaborated with, the other scientific education researchers I have collaborated with, the doctoral students I have collaborated with. All of those people have enriched my thinking tremendously.

PF: Sandi, I appreciate your honesty in sharing that. I would say you are a prolific writer, you have published quite a bit and then I think people think, "this is a struggle that only I am having." Then to hear someone else talk about that and then say "this is how I worked through it, this is how I was able to produce what it was I needed to write." I think that is helpful to other people to hear that and we tend to only be known by our published work, the final product, and not know so much about the process that occurred.

I would like to thank you for sitting down on a snowy December afternoon with me, and having this conversation about research and science teacher education. Again, I would like to thank you for your time.

SA: You are very welcome, it was my pleasure.

I want to thank Fatih Tasar for initiating this interview series and Sandra Abell for agreeing to participate. It is my hope that our conversation provides insights into science teacher learning research and sparks new ideas in your own research.

\section{REFERENCES}

Bybee, R. W. (2002). Scientific inquiry, student learning, and the science curriculum. In R. W. Bybee (Ed.). Learning science and the science of learning. Arlington, VA: NSTA Press.

Fenstermacher, G. D. (1994). The knower and the known: The nature of knowledge in research on teaching. In $\mathrm{L}$. Darling-Hammond (Ed.), Review of research in education, 20, 3-56. Washington, DC: American Educational Research Association.

Good, R.(1993). More guidelines for reviewing research. Journal of Research in Science Teaching, 30, 1-2.

Magnusson, S., Krajcik, J., \& Borko, H. (1999). Nature, sources and development of pedagogical content knowledge for science teaching. In J. Gess-Newsome \& N. G. Lederman (Eds.), Examining pedagogical content knowledge: The construct and its implications for science education (pp. 95-132). Boston: Kluwer.

Lortie, D. C. (1975). Schoolteacher: A sociological study. Chicago: University of Chicago Press.

Shavelson, R. J., \& Towne, L. (eds.). (2002). Scientific research in education. Washington, DC: National Academy Press.

Shulman, L. S. (1986). Those who understand: Knowledge growth in teaching. Educational Researcher, 15(2), 4-14.

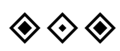




\section{Appendix: Selected Publications, Sandra K. Abell,} 1992-2008

Abell, S. K., \& Pizzini, E. L. (1992). The effect of a problem solving inservice program on the classroom behaviors and attitudes of middle school science teachers. Journal of Research in Science Teaching, 29(7), 649-667.

Abell, S. K., \& Roth, M. (1992). Constraints to teaching elementary science: A case study of a science enthusiast student teacher. Science Education, 76(6), 581-595.

Abell, S. K., \& Roth, M. (1994). Constructing science teaching in the elementary school: The socialization of a science enthusiast student teacher. Journal of Research in Science Teaching, 31(1), 77-90.

Abell, S. K., \& Smith, D. C. (1994). What is science? Preservice elementary teachers'conceptions of the nature of science. International Journal of Science Education, 16(4), 475-487.

Abell, S. K., \& Roth, M. (1995). Reflections on a fifth grade life science lesson: Making sense of children's understanding of scientific models. International Journal of Science Education, 17 (1), 59-74.

Cennamo, K. S., Abell, S. K., George, E. J., Chung, M. (1996). The development of integrated media cases for use in elementary science teacher education. Journal of Technology and Teacher Education, 4(1), 19-36.

Cennamo, K. S., Abell, S. K., \& Chung, M. (1996). A "Layers of Negotiation" model for designing constructivist learning materials. Educational Technology, 36, 39-48.

Abell, S. K., \& Bryan, L. S. (1997). Reconceptualizing the elementary science methods course using a reflection orientation. Journal of Science Teacher Education, 8(3), 153166.

Abell, S. K., Bryan, L. A., \& Anderson, M. A. (1998). Investigating preservice elementary science teacher reflective thinking using integrated media case-based instruction in elementary science teacher preparation. Science Education, 82(4), 491-510.

Bryan, L. A., \& Abell, S. K. (1999). The development of professional knowledge in learning to teach elementary science. Journal of Research in Science Teaching, 36(2), 121139.

Abell, S. K. (2000). From professor to colleague: Creating a professional identity as collaborator in elementary science. Journal of Research in Science Teaching, 37(6), 548562.

Abell, S. K. (Ed.). (2000). Science teacher education: An international perspective. Dordrecht, The Netherlands: Kluwer Academic Publishers.

Abell, S. K. , Anderson, G., \& Chezem, J. (2000). Science as argument and explanation: Inquiring into concepts of sound in third grade. In J. Minstrell and E. van Zee (Eds.), Inquiring into inquiry learning and teaching in science (pp. 65-79). Washington, DC: American Association for the Advancement of Science.

Abell, S. K., Martini, M., \& George, M. D. (2001). “That's what scientists have to do": Preservice elementary teachers' conceptions of the nature of science during a moon investigation. International Journal of Science Education, 23, 1095-1109.

Newman, W. J., Jr., Abell, S. K., Hubbard, P. D., McDonald, J., Otaala, J., \& Martini, M. (2004). Dilemmas of teaching inquiry in elementary science methods. Journal of Science Teacher Education, 15(4), 257-280.

Abell, S. K., Smith, D. C., \& Volkmann, M. J. (2004). Inquiry in teacher education. In L.B. Flick and N.G. Lederman (Eds.), Scientific inquiry and the nature of science: Implications for teaching, learning, and teacher education (pp. 173-199). Dordrecht, The Netherlands: Kluwer.

Friedrichsen, P., Lannin, J., Abell, S., Arbaugh, F., \& Volkmann, J. (2008). Examining incoming identities in an alternative certification program for mathematics and science. Eurasia Journal of Mathematics, Science and Technology Education, 4(2).

Hubbard, P., \& Abell, S. (2005). Setting sail or missing the boat: Comparing the beliefs of preservice elementary teachers with and without an inquiry-based physics course. Journal of Science Teacher Education, 16(1), 5-25.

Volkmann, M. J., Abell, S. K., \& Zgagacz, M. (2005). The challenges of teaching physics to preservice elementary teachers: Orientations of the professor, teaching assistant, and students. Science Education, 89, 847-869.

Abell, S. K. (2005). University science teachers as researchers: Blurring the scholarship boundaries. Research in Science Education, 35(3), 281-298.

Brown, P. L, Abell, S. K, Demir, A., \& Schmidt, F. J. (2006). College science teachers' views of classroom inquiry. Science Education, 90, 784-802.

Abell, S. K. (2006). Challenges and opportunities for field experiences in elementary science teacher preparation. In K. Appleton (Ed.), Elementary science teacher education: Contemporary issues and practice (pp. 73-89). Mahwah, NJ: Lawrence Erlbaum.

Abell, S. K, \& Volkmann, M. J. (2006). Seamless assessment in science: A guidebook for elementary and middle school teachers. Portsmouth, NH: Heinemann.

Park Rogers, M., Abell, S., Lannin, J., Wang, C.-Y., Musikul, K., Barker, D., \& Dingman, S. (2007). Effective professional development in science and mathematics education: Teachers' and facilitators' views. International Journal of Science and Mathematics Education, 5, 507-532.

Abell, S. K., Lannin, J. K., Marra, R. M., Ehlert, M. W., Cole, J. S., Lee, M. H., Park Rogers, M.A., \& Wang, C.-Y. (2007). Multi-site evaluation of science and mathematics teacher professional development programs: The project profile approach. Studies in Educational Evaluation, 33, 135-158.

Abell, S. K., \& Lederman, N. G. (Eds). (2007). Handbook of research on science education. Mahwah, NJ: Lawrence Erlbaum.

Abell, S. K. (2007). Research on science teacher knowledge. In S. K. Abell and N. G. Lederman (Eds). Handbook of research on science education (pp. 1105-1149). Mahwah, NJ: Lawrence Erlbaum.

Chval, K., Abell, S., Pareja, E., Musikul, K., Ritzka, G. (2008). Science and mathematics teachers' experiences, needs, and expectations regarding professional development, Eurasia Journal of Mathematics, Science and Technology Education, 4(1) 31-43

Abell, S. K. (in press). PCK twenty years later: Does it remain a useful idea? International Journal of Science Education (special issue on PCK). 